\title{
CHANGES IN THE RANK OF WORLD ECONOMIC CENTERS IN THE UNITED STATES - PRESENT STATE AND PERSPECTIVES
}

DOI: http://dx.doi.org/10.18509/GBP.2018.25

UDC: 332.122(73) 334.73(73)

\author{
Piotr Raźniak \\ Slawomir Dorocki \\ Anna Winiarczyk-Raźniak \\ Institute of Geography, Pedagogical University of Krakow, Poland
}

\begin{abstract}
The purpose of the study was to determine the level of resilience of the command and control function via its dominant sector in cities in the United States and forecast the level of resilience for the period up to 2025. Changes in the WECI index were used to analyze this issue. The index is calculated based on standardized values of financial data of companies located in major metropolitan areas with a special focus on economic potential and the variety of sectors present. The number of corporate headquarters decreased in most cities in the U.S. (designated world economic centers) in the period 2006 - 2016, while the resilience of their main sectors increased. The most important WECs in the United States today are New York, Chicago, Houston, and San Jose. Research has shown that the resilience of U.S. cities tended to increase in a lagging manner with respect to the market value of U.S. companies following the 2008 global financial crisis. The forecast for 2025 suggests that the leading WECs in the U.S. will be New York, Chicago, San Jose, and San Francisco. No spatial patterns were noted in future changes in WECI values. Both decreases and increases in WECI values occur more or less evenly across the United States. Changes in U.S. WECI values also do not appear to be related to a one specific sector of the U.S. economy.
\end{abstract}

Keywords: corporation, headquarters, industry sectors, world economic center

\section{INTRODUCTION}

The role of major corporations present in cities around the world has been examined by researchers for several decades. Corporations serve as an important component of current globalization processes and affect linkages between main cities around the world [1], [2], [3]. Their role in globalization increases to the point where cities produce a greater impact on the modern economy than do countries [4]. According to [5], [6], globalization manifests itself also in the establishment or acquisition of plants in countries with lower labor costs. In some cases, corporations establish sales offices in new countries, which strengthens business linkages between [7], [8]. Hence, the general pattern is that of an international economic system that enhances linkages between corporations and also between cities [9]. It also can be said that there is a positive impast of network economy on global trade and economy by reducing costs [10]. The location of a given company's headquarters and its actual place of business may be different in some cases. This is especially true of companies with multiple divisions in sectors such as finance, services, and trade. This pattern is less often observed in the case of industrial companies. In summary, this means that the location of company headquarters is associated more with 
the control function than with the actual location of production resources [11]. It appears that research on the location of company headquarters for the largest global corporations displays the unique power of cities in the realm of control and management in the world economy - and this is one of the many measures of city rank in the world (Taylor, 2004). The headquarters of the largest corporations in the world produce the control and management function of cities. In the view of [12], it is corporations listed by Forbes Global 2000 that produce this function for cities on a global scale. Cities are also examined in this respect by continent [27] primary geographic region [13] and by country [14], [15]. The control and management function is also analyzed in terms of how a region may attract research and development staff and facilities [16] and the concentration of this function in different areas of the world [17].

The newest ideas in this area of study tend to focus on potential changes in the control and management function in cities in times of crisis in a city's principal economic sector. The newest research covers global examples [18], [19] and specifically the region of Eastern Europe [20], [21].

Given the dominance of U.S. cities in the world economy in the area of control and management [22], it is reasonable to examine the extent to which their control and management function is able to withstand crisis events in dominant sectors of the economy in the United States. The present study also provides forecasts up to the year 2025 .

\section{DATA AND METHODS}

The study uses data obtained from the Forbes Global 2000 list [23] and aggregated at the metropolitan area level for cities with large metropolitan areas featuring key corporate headquarters [22]. Data such as corporate revenue, profit, market value, and fixed asset value were examined for the years 2006-2016. The data were then totaled for major metropolitan areas with corporate headquarters. The number of headquarters per city was also determined. In addition, the number of economic sectors per city was determined via the classification established by Standard \& Poor's (Global Industry Classification Standard: GICS).

The paper provides a comparison of the control and management potential of selected metropolitan areas via a calculation of standardized values based on normalized values of data provided in corporate financial reports for corporations headquartered in each studied city. In this step of the research process, data such as revenue, profit, market value, and fixed asset $(\mathrm{x})$ value were determined for each studied sector $(\mathrm{z})(1)$. The data were then totaled in order to produce a comprehensive index of potential for each studied metropolitan area $\left(\mathrm{SWP}_{\mathrm{Sz}}\right)(2)$. The analysis focused only on cities with four or more main sectors of the economy.

$$
\begin{aligned}
& z_{k}=\sum \frac{x-\frac{\sum_{i=1}^{N} x_{i}}{m}}{s_{x}} \\
& S W P_{S Z}=\sum_{i=1}^{N} z_{k_{i}}
\end{aligned}
$$


where

$\mathrm{x}$ - profit, revenue, market value, fixed asset value for selected metropolitan areas

$\mathrm{k}-$ sectors

$\mathrm{m}$ - number of large metropolitan areas per given sector

$\mathrm{s}$ - standard deviation for $\mathrm{x}$

SZ - corporate headquarters

Calculations were performed for the years 2006-2016 in order to assess changes in values. A test was performed to see which economic sector yields the strongest effect on the control and management potential of a given city by subtracting individual sector values from the index of potential for each given metropolitan area $\left(\mathrm{SWP}_{\mathrm{SZ}}\right)$. This made it possible to check the change in standardized values ( $\mathrm{z}^{\prime}$ ) for each studied country assuming that each initial value equals $100 \%$ (3).

$$
z^{\prime}=\frac{S W P_{S Z}-z_{k}}{S W P_{S Z}} 100
$$

This calculation yields cities with the strongest area of economic specialization and also the weakest sectors of the economy. The lower the value following subtraction of a given sector, the more dependent the control and management potential on companies belonging to a single sector, which may have been affected by economic fluctuations on the international stage in that particular sector. Metropolitan areas characterized by large differences in potential values between maximums and minimums following single sector subtraction are also characterized by high specialization in one area of the economy and inadequate development in some other areas of the economy. On the other hand, metropolitan areas characterized by small maximum versus minimum differences may be said to have evolved in a comprehensive manner in terms of their regional economies. The data utilized in the study were used to construct an index of stability (IS) via the division of the $\mathrm{SWP}_{\mathrm{SZ}}$ index by the standard deviation $\mathrm{S}$ of values obtained following sector subtraction ( $\left.z^{\prime}\right)(4)$.

$$
I S=\frac{S W P_{S Z}}{S_{z^{\prime}}}
$$

The higher the index value, the greater the stability - defined to be the lack of strong economic specialization - of development across all analyzed sectors of a region's economy. The index also illustrates just how crisis in a principal sector of the economy may affect the economic success of a given metropolitan area.

A comprehensive world economic center index (WECI) was [19] in order to assess levels of sustainable global potential of major metropolitan areas. The index includes information from other indexes such as the index of stability and the number of economic sectors and the number of corporate headquarters. These elements are weighted at $50 \%, 30 \%$, and $20 \%$, respectively (5). The index of stability shows the strength of a city and its metropolitan area. A large number of sectors may yield a stabilizing effect on the region in the event of a crisis in one or more economic sectors. Both sets of data are 
largely dependent on the number of corporate headquarters present in the given metropolitan area. Hence, WECI consists of both information on the economic potential of a region and its ability to respond to economic crisis. WECI analysis makes it possible to more fully compare the potential of cities and their metropolitan areas with respect to "corresponding" cities and metropolitan areas, i.e. those with similar stability index values.

$W E C I=\frac{50 I S+30 k+20 S Z}{100}$

where $\mathrm{SZ}$ is the number of corporate headquarters

$\mathrm{k}$ - number of sectors

Aby zrozumieć rodzaje zmian zachodzących w systemie miast i jaka była pozycja międzynarodowa można zastosować inne wskaźniki, wśród których można wyróżnić miary rank oraz udziału procentowego wybranych wskaźników potencjału ekonomicznego [24]. Trend analysis based on linear regression [25] was utilized to determine WECI values and the sector structure of selected major metropolitan areas for the years 2011-2016 or the period following the global financial crisis of 2008 [26].

It is important to note that calculations cannot be performed when the mean value for a given sector equals zero. Normalization was performed basing on the normal distribution and does not include an assessment of the asymmetricity of the data used. The normal distribution was assumed to be sufficient in this study. This issue needs to be considered when analyzing data - and normalization should not be performed for strongly skewed distributions.

\section{CORPORATIONS ACROSS THE WORLD}

The number of corporate headquarters in traditionally strong economies such as the United States and Japan decreased over the study period. A total of 703 headquarters in 2006 were located in the United States, which represented 35\% of corporations listed on the Forbes Global list. This value declined systematically until 2012 and began to increase in 2013. The overall decline for the period 2006-2016 was $16 \%$.

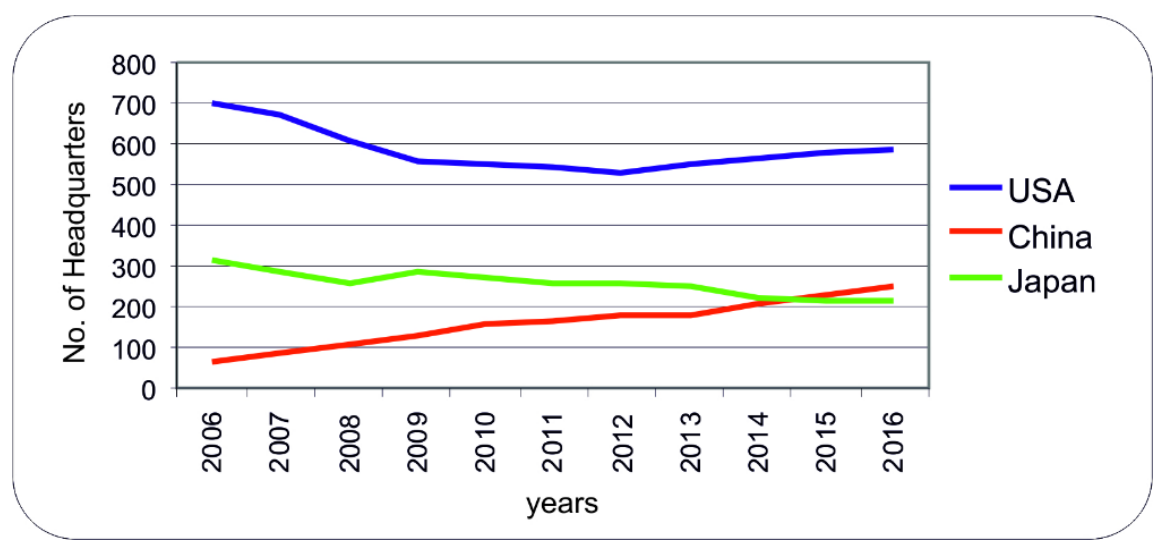

Figure 1. Number of corporate headquarters by three dominant countries Author's own work based on G. Csomós, 2017 
A different pattern was noted for Japan. In the years 2006-2008, the number of corporate headquarters decreased, then increased in 2009 and then continued its decline for the next several years. In the period 2006-2016, the decline in Japan stood at 32\% or twice the rate for corporations in the United States. The situation in China was found to be quite different for the same period of time. Only 64 corporations listed by Forbes Global 2000 were noted in China in 2006 or 3.2\% of the total on the list. By 2016 the number of Chinese corporations on the list had increased to 249 for an equivalent rise of $342 \%$ (12\% of total number). Of the three countries studied, only China experienced a steady growth in the number of Forbes-listed corporations from year to year. Even the global crisis of 2008 did not force a decline in the number of Forbes-listed Chinese corporations, as in the case of American and Japanese corporations. Japan was ranked second for many years until 2015 when China ascended into second place in terms of the number of Forbes-listed firms in the world. China's advantage over Japan increased further in 2016 (Fig. 1).

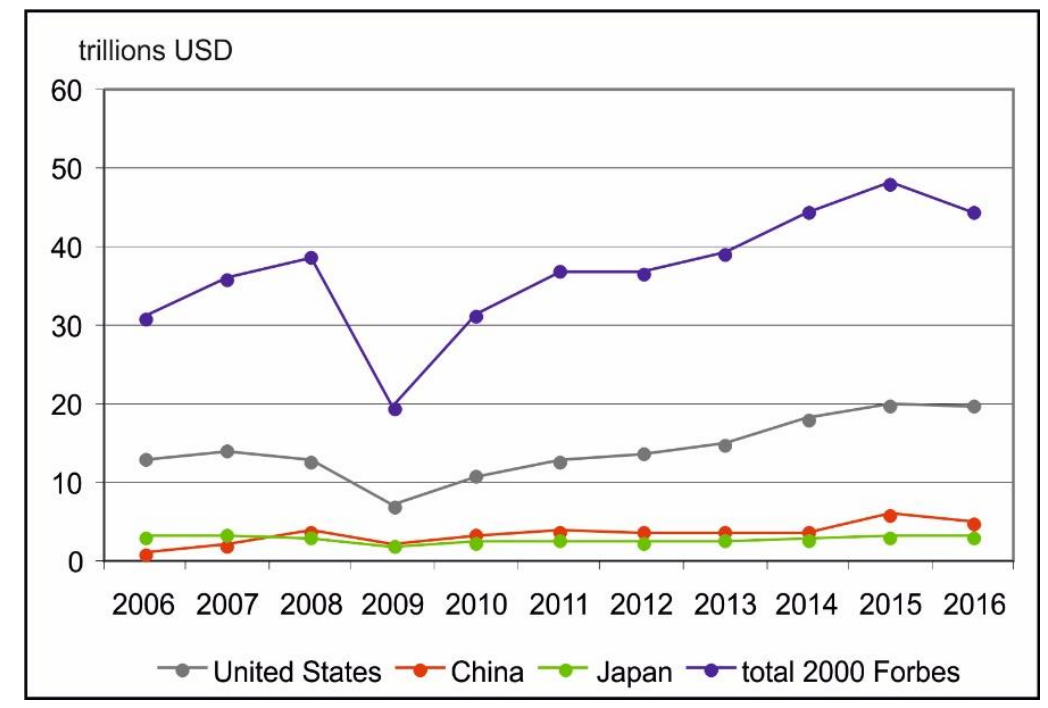

Figure 2. Company market value for the years 2006-2016 in trillions (USD)

Author's own work based on G. Csomós, 2017

The most general pattern for the study period is that of a global increase in the market value of global corporations. While the total market value of 2,000 leading corporations in 2006 was 31 trillion USD, their total market value in 2016 increased to 44.5 trillion USD. A rather large decline in market value did occur in 2009 due to the 2008 global financial crisis. It took the 2,000 leading corporations two years to recover to their precrisis market value. A large decline in corporate market value occurred for all "big three" economies, but the loss in Japan was the smallest at 38\%. The loss of market value was similar in China and the United States at $46 \%$ and $45 \%$, respectively. It may be argued that U.S. corporations handled the loss better than their Chinese counterparts. This is shown by the fact that the number of corporate headquarters declined in the United States in the period 2008-2009, while increasing in China. The mean loss in market value was consequently smaller (per company) in the United States. The loss in market value in China was $1 \%$ larger despite a larger number of corporations (Fig. 2). 


\section{WORLD ECONOMIC CENTERS IN THE USA}

A total of 25 U.S. cities were selected for analysis using the WEC index. The leader in the number of U.S. corporate headquarters in both 2006 and 2016 was New York City. The next two cities were ranked much lower - Chicago and San Jose. Data for 2006 shows that of major U.S. cities located in traditionally strong industrial regions such as the BosNy-Wash megalopolis and the so-called Rust Belt Chicago-Toronto megalopolis, the top ten cities include only New York, Chicago, Minneapolis, and Washington D.C..

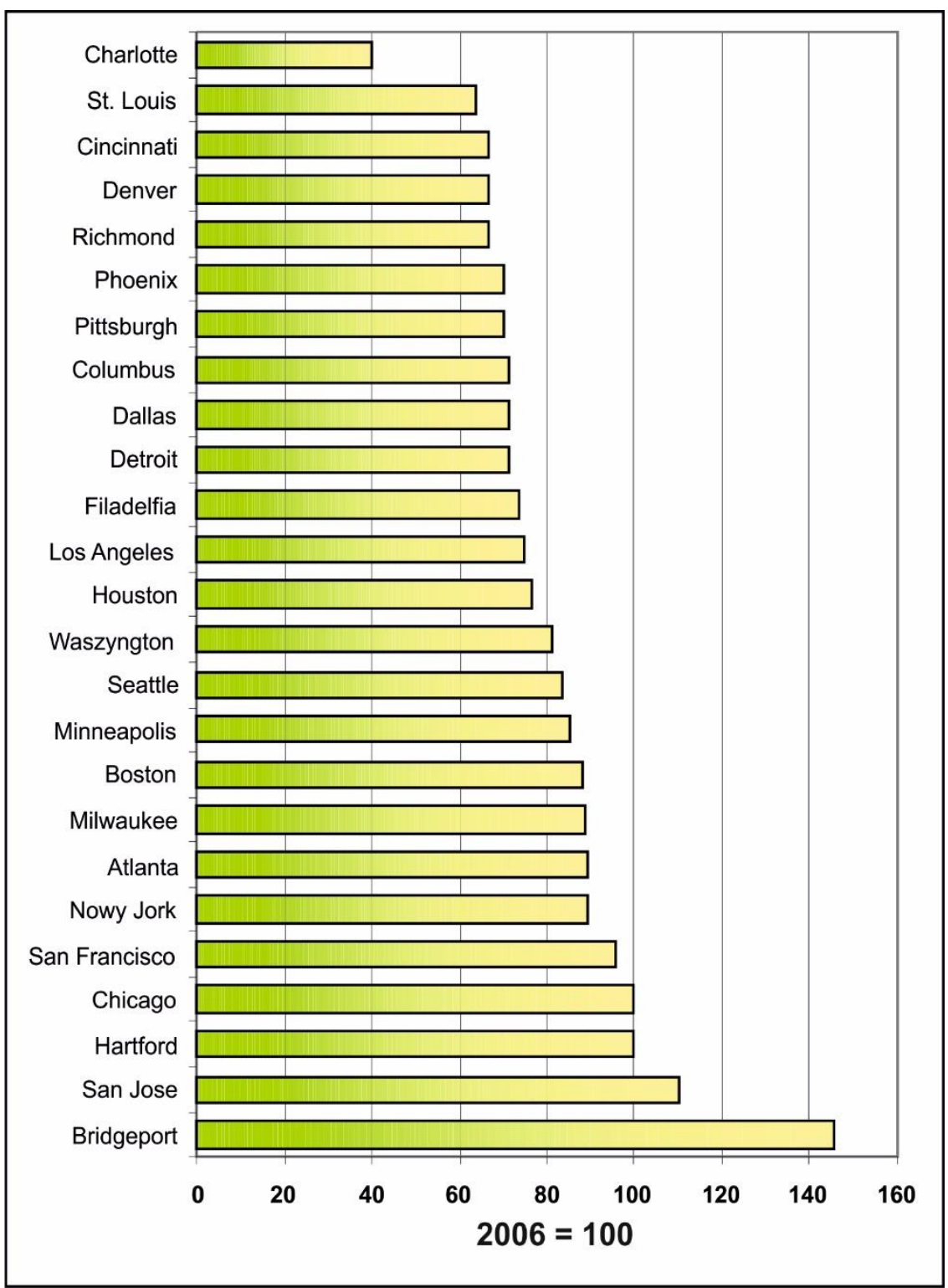

Figure 3. Number of corporate headquarters in the years 2006-2016 Author's own work based on G. Csomós, 2017

The two regions had played a key role in the American economy already in the $19^{\text {th }}$ century. The remaining six cities were found in the southern and southeastern parts of the country. Only two cities on the list experienced an increase in the number of corporate headquarters in the study period. One of these cities was Bridgeport in Connecticut with an increase of $45.5 \%$. The city is located relatively close to New York and its attractiveness may be due to its close proximity to a leading global center of economics. 
On the other hand, 21 of the 25 studied cities experienced declines, the largest of which occurred in Charlotte, St. Louis, Cincinnati, Denver, and Richmond (Fig. 3).

Table 1. Comprehensive WEC index for U.S. cities in 2006 - 2025

\begin{tabular}{|r|r|r|r|}
\hline \multicolumn{1}{|l|}{ Year } & WEC Index & \multicolumn{1}{l|}{ Year } & WEC Index \\
\hline 2006 & 161,5 & 2013 & 131,4 \\
\hline 2007 & 151,1 & 2014 & 135,4 \\
\hline 2008 & 142,7 & 2015 & 135,5 \\
\hline 2009 & 134,4 & 2016 & 141,7 \\
\hline 2010 & 134,5 & 2020 & 150,2 \\
\hline 2011 & 129,5 & 2025 & 163,0 \\
\hline 2012 & 127,1 & & \\
\hline
\end{tabular}

Author's own work based on G. Csomós, 2017

The comprehensive WEC index for U.S. cities for 2006 equaled 161.5. The resistance of the control and management function to crisis declined until 2012 even though the value of U.S. corporations began to rebound in 2010. On the other hand, most world economic centers in the United States experienced a decline in the number of corporate headquarters, which can naturally affect the value of the WEC index. Increases in the index were noted again in 2012 and its value systematically increased until the final year of analysis (2016) when it equaled 141.7 or $12 \%$ less than its value in 2006. U.S. cities are expected to return to their 2006 level of resistance to crisis in the year 2025, as their control and management function continues to rebound from its substantial decline following the global financial crisis of 2008 (Tab. 1).

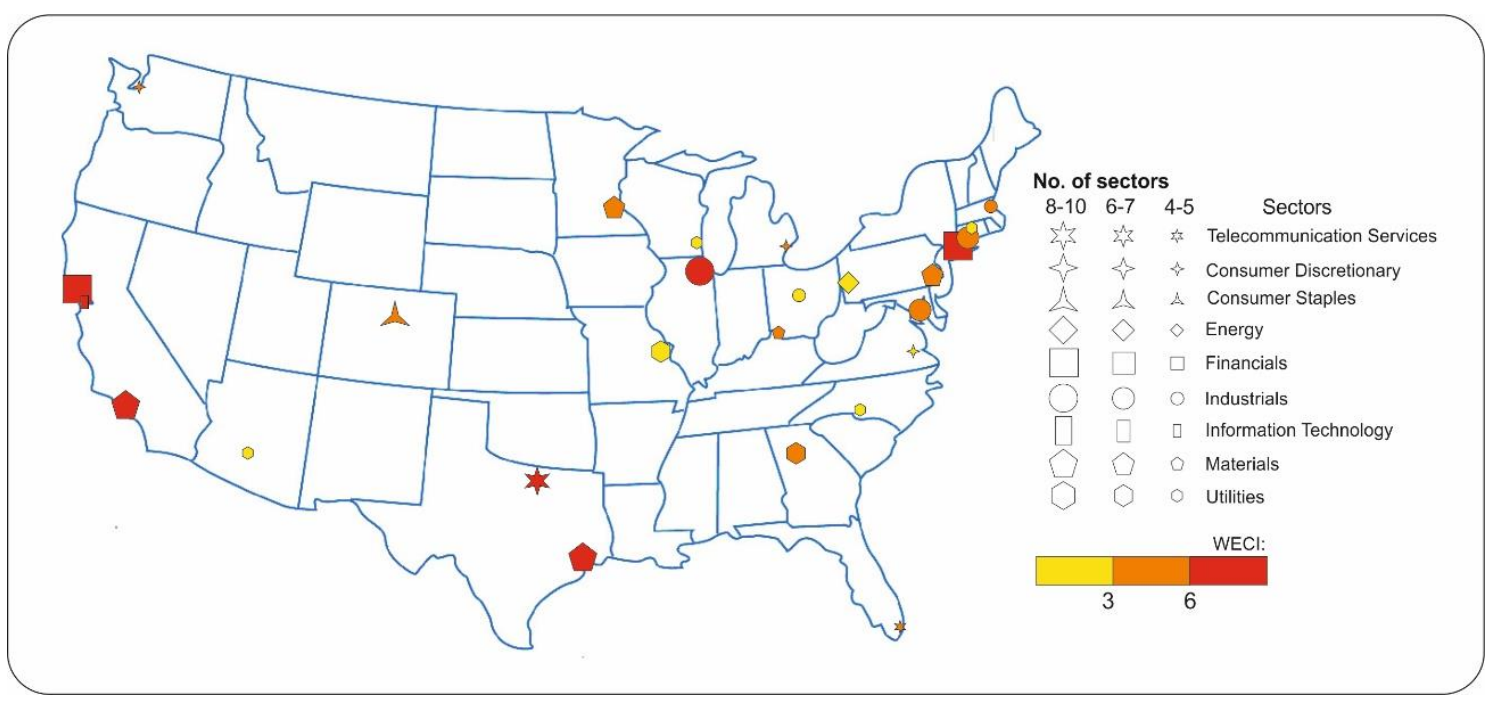

Figure 4. World economic centers and dominant sectors in 2016 in the U.S.

New York City is the decisive leader in terms of WEC index values and its ability to resist crisis in its control and management function caused by a decline in the market value of firms part of the dominant economic sector in the city $(\mathrm{WECI}=23.5)$. The city is followed by Chicago (10.7), San Jose (7.9), Houston (7.3), and San Francisco (7.2). U.S. world economic centers are most often located in the northeastern part of the country, with only Seattle in the northwest, with a relatively low WEC value of 3.5. Of the ten economic sectors identified by Standard \& Poor's, every sector is dominant in at least one U.S. city. The sectors that are most often dominant in U.S. cities were the media (6 cities), raw materials (5 cities), discretionary consumer spending (4 cities), and industry (4 cities). 
The following sectors were dominant in only one city each: consumer goods, energy, healthcare, IT, telecommunications (Fig. 4).

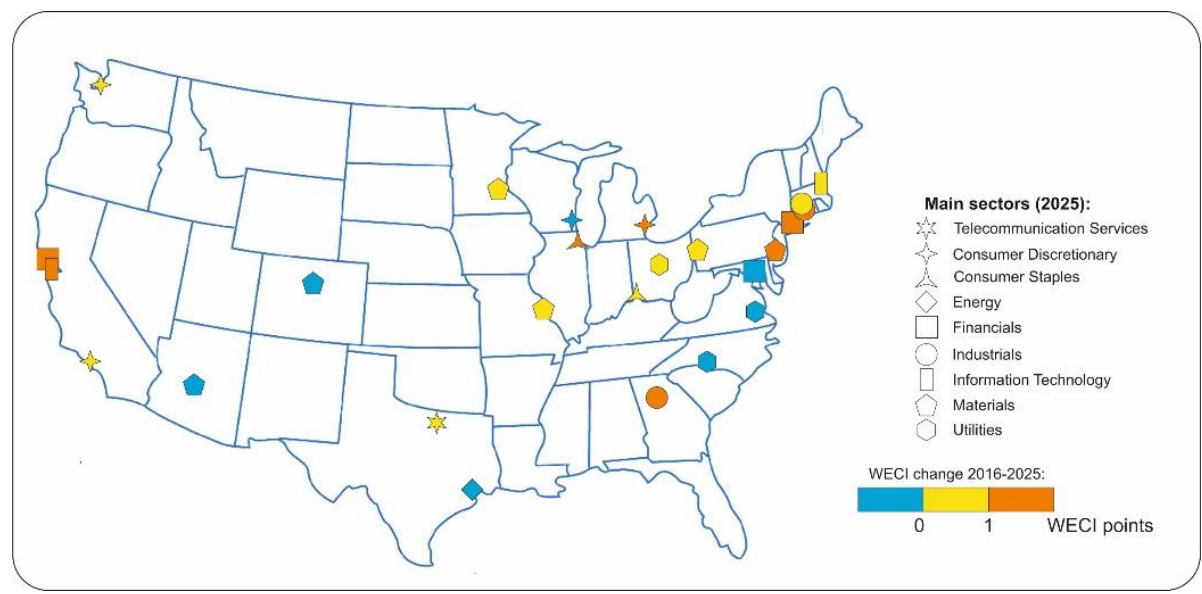

Figure 5. Forecast for WEC index values for the years 2016-2025

The forecast for 2025 shows a lack of change among cities most resistant to crisis in their dominant economic sector. The top three cities remain unchanged: New York, Chicago, San Jose. The three cities are also expected to experience an increase in resistance to crisis in the range from 2.3 to $2.5 \mathrm{WEC}$ index points. The increase in resistance to crisis is expected to be greater only in the case of Atlanta (3.0). However, not all world economic centers in the U.S. will experience increases in resistance. Seven cities will become more susceptible by the year 2025 relative to 2016: Richmond, Houston, Washington, Charlotte, Milwaukee, Phoenix, Denver. All seven cities already do not possess a high WEC index value in 2016. The largest declines in stability will be noted for Denver (1.9), Phoenix (-1.8), Milwaukee (-1.5). Sector differences will not change substantially between 2016 and 2025 (Fig. 5). The raw materials sector will dominate the economies of six U.S. world economic centers in 2025 (5 in 2016). Discretionary consumer spending will dominate four cities in 2025 - the same as in 2016 . The media will be the dominant sector in four cities in 2025 compared with six cities in 2016. At the same time, healthcare will no longer dominate in any world economic center in the U.S. in 2025, with predominance in 2016 only in San Diego.

\section{RESULTS}

Despite the occurrence of economic crises from time to time, the largest corporations gain in strength due to the effects of globalization. Many are considered "too big to fail" and may count on government financial assistance in the event of a major crisis. Cities home to major corporations boast the ability to control and manage the world economy. The current leader in this respect is Beijing followed by New York, Tokyo, London, and Paris. Despite the global financial crisis of 2008, the United States continues to lead in the area of global corporations - 30\% of all corporations listed by Forbes Global 2000 have their headquarters in this country. Japan was the second largest concentrator of corporations until recently, but was replaced by China in 2015 , which is constantly advancing in world rankings. The number of headquarters declined in most U.S. world economic centers between 2006 and 2016, although the level of resistance of principal sectors to crisis did increase over the same time period. At this time, the most important world economic centers in the U.S. are New York, Chicago, Houston, San Jose, and San Francisco. It is 
noteworthy that the resistance of U.S. cities to crisis increased later relative to their increase in market value following the global financial crisis of 2008.

Forecasts indicate that Atlanta, San Jose, and San Francisco will strengthen the most by 2025 - more than the strongest U.S. cities such as New York and Chicago. The largest decline is expected to affect Milwaukee, Charlotte, Denver, and Washington D.C.. Changes in locally dominant sectors will be minor. The main dominant sectors in 2025 will be raw materials ( 6 cities), media (4 cities), and discretionary consumer spending (4 cities). Changes in the WEC index values for 2025 will not vary spatially. Both increases and decreases in WEC value will occur more or less evenly across the United States. WECI rates of change are also not affected by any specific sector of the economy. It appears that for a city to grow in an economically stable manner in terms of its control and management function, it needs to possess several economic sectors and not be limited by the dominance of a single sector. When a crisis occurs in a primary regional sector, its effects are less pronounced if this sector does not overly dominate other main sectors in the region. Hence, diversity of economic sectors is one goal which cities ought to pursue in order to yield a stable control and management function. On the other hand, a stable city with a diverse local economy may be less recognizable in the world, as opposed to cities with a renowned primary sector including New York as the financial capital of the world and San Jose as the IT capital of the world.

\section{REFERENCES}

[1] Hall, P. The World Cities. London: Heinemann, 1966.

[2] Friedmann, J. The world city hypothesis, Development and Change, vol 17(1), pp 69-83, 1986, DOI: 10.1111/j.1467-7660.1986.tb00231.x.

[3] Beaverstock, J.V \& Smith, R.G. \& Taylor, P.J. A rooster of world cities. Cities, vol 6(6), 1999, pp 445-458.

[4] A.T. Kearney. Global Cities Index and Emerging Cities Outlook, 2012.

[5] Kilar, W. Korporacje informatyczne jako element struktury metropolii. Studia Komitetu Przestrzennego Zagospodarowania Kraju PAN, vol 125, pp 136-153, 2009.

[6] Zioło, Z. Procesy kształtowania się światowych korporacji i ich wpływ na otoczenie. Prace Komisji Geografii Przemysłu Polskiego Towarzystwa Geograficznego, vol 12, pp 11-31, 2009.

[7] Liu, X. \& Derudder, B. \& Taylor, P.J. Mapping the evolution of hierarchical and regional tendencies in the world city network 2000-2010. Computers, Environment and Urban Systems, vol 43, pp 51-66, 2014.

[8] Zuzańska-Żyśko E. Procesy metropolizacji. Teoria i praktyka, Warszawa: PWN, 2016.

[9] Sassen, S. The Global City: Strategic Site/New Frontier, American Studies, vol 41(2/3), 2000.

[10] Lv, X.. Study on the Influence of Network Economy on International Economy and Trade. Journal of Finance Research, vol 1(1), pp 1-4, 2017. DOI: http://dx.doi.org/10.26549/jfr.v1i1.378 [11] Śleszyński, P. Economic control functions in Poland. Geographia Polonica, vol 88(4), pp 701-708, 2015. http://dx.doi.org/10.7163/GPol.0041.

[12] Taylor, P.J. \& Csomós G. 2012. Cities as control and command centres: Analysis and interpretation. Cities, vol 29(6), DOI:10.1016/j.cities.2011.09.005

[13] Raźniak, P. \& Dorocki, S. \& Winiarczyk-Raźniak, A. Eastern European cities as command and control centres in time of economic crisis. Acta Geographica Slovenica, vol 58(2), pp 101110, 2018.doi: http://dx.doi.org/10.3986/AGS.3124. 
[14] Śleszyński, P. Gospodarcze funkcje kontrolne w przestrzeni Polski. Warszawa: IGiPZ PAN, 2007.

[15] Szajnowska-Wysocka A. \& Zuzańska-Żyśko E. The Upper-Silesian conurbation on the path towards the "Silesia" metropolis. Bulletin of Geography. Socio-economic Series, vol 21, pp 111124,2013 ,

[16] Tóth, G. \& Csomós, G. Mapping the position of cities in corporate research and development through a gravity model-based bidimensional regression analysis. Regional Statistics, vol 6(1), pp 217-220, 2016. DOI: 10.15196/RS06111

[17] Csomós, G. \& Tóth, G. Featured Graphic. Modelling the shifting command and control function of cities through a gravity model based bidimensional regression analysis. Environment and Planning A, vol 48(4), pp 613-615, 2016. DOI: 10.1177/0308518X15621632.

[18] Raźniak, P. \& Dorocki, S. \& Winiarczyk-Raźniak, A. Kryzys gospodarczy a funkcje kontrolno-zarządcze miast w dobie globalizacji. OPTIMUM. Studia Ekonomiczne, vol 79(1), pp 100-117, 2016.

[19] Raźniak, P. \& Dorocki, S. \& Winiarczyk-Raźniak, A. Permanence of Economic Potential of Cities Based on Sector Development, Chinese Geographical Sciences, vol 27(1), pp123-136, 2017. DOI: 10.1007/s11769-017-0850-5

[20] Raźniak, P. \& Dorocki, S. \& Winiarczyk-Raźniak, A. \& Płaziak M. \& Szymańska A.I. Lokalizacja ośrodków kontroli i zarządzania elementem stabilności gospodarczej ośrodków miejskich w Europie Środkowo-Wschodniej. Prace Komisji Geografii Przemysłu Polskiego Towarzystwa Geograficznego, vol 2(30), pp 38-54. 2016.

[21] Raźniak, P. \& Dorocki, S. \& Winiarczyk-Raźniak, A. \& Płaziak, M. \& Szymańska, A.I. Zmiany pozycji ekonomicznej miast Europy Środkowo-Wschodniej w przypadku kryzysu dominującego sektora. Ekonomista, vol 2017(1), pp 67-83. 2017.

[22] Csomós, G. Cities as Command and Control Centres (2006-2016). Harvard Dataverse, 2017, doi:10.7910/DVN/TLPDMS.

[23] www.forbes.com, acess 15.11.2013

[24] Jażdżewska, I. Spatial and dynamic aspects of the rank-size rule method. Case of an urban settlement in Poland. Computers,. Environment and Urban Systems vol. 62, pp 199-209, 2017. DOI: http://dx.doi.org/10.1016/j.compenvurbsys.2016.11.006

[25] Tarczyński, W. Wyznaczanie trendu w analizie technicznej na podstawie linii regresji. Zeszyty Naukowe Uniwersytetu Szczecińskiego. Prace Katedry Ekonometrii i Statystyki, vol 9, pp 9-27, 2000.

[26] Dorocki, S. Wpływ kryzysu gospodarczego na przemiany struktur regionalnych Francji. Prace Komisji Geografii Przemysłu Polskiego Towarzystwa Geograficznego, vol 17, pp 67-86, 2011. DOI:10.24917/339.

[27] Raźniak, P. \& Winiarczyk-Raźniak, A. Did the 2008 global economic crisis affect large firms in Europe? Acta Geographica Slovenica, vol 55(1), pp 127-139, 2015. DOI: http://dx.doi.org/10.3986/AGS.740 